DOI.

https://doi.org/10.22219/fths.v2i1

Received: November 2018

Accepted: Desember 2018

Available online: Februari 2019

\title{
Pembuatan Cookies Substitusi Tepung Talas (Colocasia Esculenta (L) Schot) dan Tepung Daun Kelor (Moringa Oleifera Lamk)
}

\author{
Dila Yunita Ardianti ${ }^{1}$, Sukardi ${ }^{1 *}$, Rista Anggriani ${ }^{1}$ \\ ${ }^{1}$ Program Studi Ilmu dan Teknologi Pangan, Fakultas Pertanian Peternakan Universitas \\ Muhammadiyah Malang, Malang, Indonesia \\ *Corresponding author email : sukardi@umm.ac.id
}

\begin{abstract}
Cookies are product that have sweet taste with ingredients derived from wheat flour. Wheat flour can be replaced with local raw materials, such as taro flour. Moreover cookies needs to be added to functional compounds, namely Moringa leaf flour which has antioxidant properties and give a green color to the product produced. The purpose of this study was to determine the physical chemical and organoleptic cookies substituted with taro flour and fortificated with Moringa leaf flour and to determine the effect of using taro flour and Moringa leaf flour on antioxidant activity in cookies. This study used a Completely Randomized Design (CRD) which is arranged in a simple manner and with data retrieval, which each study carried out 4 replications. The factor, was the concentration of taro flour and moringa leaf flour. The parameters analyzed were water content, ash, protein, fat, carbohydrate, fiber,activity of antioxidants, and color. While organoleptic test were color, taste, and texture. Cookies for substitution of taro flour and fortification of moringa leaf flour have a very significant effect on $\mathrm{K1}$ (Wheat flour $40 \mathrm{~g}+$ Taro flour $50 \mathrm{~g}+$ Moringa leaf flour $10 \mathrm{~g}$ ) on parameters $1.92 \%$ of water, $2.11 \%$ of ash, $23.34 \%$ of fat, $7.52 \%$ of protein in color parameters produces greenish color (a-) 4.65 and yellowish color $(b+)$ 15.83, and organoleptic test appearance 2.60 , in treatment K5 (Wheat Flour $40 \mathrm{~g}+$ Taro flour $58 \mathrm{~g}+$ Moringa leaf flour $2 \mathrm{~g}$ ) had a very significant effect on fiber content parameters $0.18 \%$, carbohydrate content $71.59 \%$, texture $36.43 \mathrm{~N} / \mathrm{m}^{2}$ and in the organoleptic test taste 3.60, treatment K4 ( $K 4: 40 \mathrm{~g}$ of Wheat flour, $56 \mathrm{~g}$ of Taro flour, $4 \mathrm{~g}$ of Moringa leaf flour) has the highest brightness test value ( $L$ ) of 46.00 and in the highest value organoleptic parameters of treatment $\mathrm{K3}$ ( $40 \mathrm{~g}$ of Wheat Flour, $54 \mathrm{~g}$ of Taro Flour, $6 \mathrm{~g}$ of Moringa leaf flour) of 2.75.
\end{abstract}

Keywords: antioxidants, cookies, fiber, Moringa leaf flour, Taro flour

\section{PENDAHULUAN}

Cookies adalah salah satu jenis produk pangan yang digemari oleh masyarakat dari berbagai kalangan usia. Oleh karena itu, cookies saat ini menjadi makanan yang cukup popular dan dapat ditemukan dengan mudah. Cookies termasuk dalam kategori biskuit yang bahan bakunya terdiri dari 
tepung terigu, telur, gula, dan margarine yang dibuat melalui tahap pencampuran, pencetakan dan pemanggangan. Umumnya cookies berukuran kecil, memiliki bentuk yang datar maupun agak timbul. Lemak dan gula berperan penting terhadap karakteristik cookies yang dihasilkan. Kebutuhan terigu di indonesia masih sangat tinggi, berdasarkan data badan pusat statistik (BPS). Impor gandum pada kuartar pertama sebesar 1,3 juta/ton (Jefriando, 2013). Berdasarkan data tersebut diperlukan bahan pangan yang mensubtitusi penggunaan tepung terigu di Indonesia.

Ketergantungan penggunaan tepung terigu di industri pangan Indonesia, salah satunya dapat diatasi dengan memanfaatkan bahan baku lokal, salah satunya adalah umbi talas yang dapat diolah menjadi tepung talas (Colocasia esculenta, L. Schott). Talas adalah salah satu sumber pangan yang penting bagi tubuh diantaranya sumber karbohidrat, protein dan lemak, talas memiliki beberapa unsur mineral dan vitamin yang dapat dimanfaatkan bahan obatobatan serta dapat digunakan sebagai pengganti nasi karena talas mengandung banyak karbohidrat dan protein, sedangkan pada daun talas terkandung sumber nabati. Talas dapat dijadikan pengganti tepung dalam pembuatan kue, cake dan roti. Namun, masih ada keterbatasan penggunaan tepung dari umbi-umbian untuk menggantikan tepung terigu, dikarenakan kandungan seratnya yang tinggi sehingga mempengaruhi proses pembentukan adonan.

Tanaman kelor merupakan salah satu jenis tanaman yang memiliki sumber gizi berkhasiat sebagai obat-obatan, daun kelor memiliki potensi dapat menyencegah berbagai penyakit (Krisnadi, 2013). Pada umumnya daun kelor hanya dikonsumsi sebagai sayur-sayuran dan pakan ternak, dilihat dari kandungan vitamin C pada daun kelor mencapai $220 \mathrm{mg} / 100 \mathrm{~g}$ serta serat sebesar $16,857 \mathrm{~g} / 100 \mathrm{~g}$, oleh karena itu daun kelor dapat diolah menjadi tepung daun kelor dan tepung talas yang dijadikan sebagai subtitusi tepung terigu dalam pembuatan cookies. Dengan adanya pengembangan substitusi pembuatan cookies diharapkan dapat mengurangi kebutuhan konsumsi tepung terigu, memenuhi kebutuhan gizi pada tubuh dan menjadi camilan sehat bagi semua kalangan usia.

\section{METODE PENELITIAN}

Bahan

Bahan baku yang digunakan dalam pembuatan cookies yaitu Tepung terigu dimalang dan tepung talas yang diperoleh di Bogor, daun kelor berwarna hijau tua, umur daun lebih dari 3 tahun dengan ukuran daun kelor berkisar 2-3 cm yang diperoleh di Mojokerto. 
Alat

Alat utama yang digunakan dalam penelitian ini adalah timbangan analitik, oven, desikator, hotplate.

\section{Pembuatan Tepung Daun Kelor (Moringa oleifera)}

Sampel daun kelor yang digunakan adalah daun kelor yang berwarna hijau tua. Proses selanjutnya daun kelor dicuci dengan menggunakan air yang mengalir kemudian dipisahkan dari tangkai kelor (dirontokkan) kemudian ditebar di atas loyang pengering. Daun kelor tersebut selanjutnya dikeringkan dengan pengeringan menggunakan cabinet dryer dengan suhu $45^{\circ}-50^{\circ} \mathrm{C}$ selama 24 jam. Setelah daun kelor kering, selanjutnya ditepungkan dengan menggunakan blender kemudian diayak menggunakan ayakan 80 mesh. (Zakaria, dkk., 2012).

\section{Pembuatan Cookies}

Pembuatan cookies menggunakan metode creaming, yaitu telur dan gula diaduk hingga setengah mengembang, supaya gula larut dalam telur dan telur mengikat udara (adonan pertama) di sisi lain margarin, butter dan baking powder diaduk hingga homogen dengan ditandai berwarna pucat (adonan kedua), kemudian adonan tersebut tercampur rata beserta tepung dan susu bubuk hingga homogen. Pembuatan cookies ini menggunakan butter untuk bertujuan menambah aroma serta untuk memudahkan pemindahan cookies dari loyang (tidak lengket) (Pratiwi, 2008).

\section{Parameter Penelitian}

Parameter pengamatan yang dilakukan terdiri dari uji fisik, kimia, dan uji organoleptik. Parameter yang diamati pada produk cookies adalah analisa kimia kadar air, kadar lemak, protein, karbohidrat, serat pangan kasar dan antioksidan. Diuji fisik daya patah, serta uji organoleptik.

\section{Rancangan Percobaan dan Analisa Data}

Rancangan yang digunakan dalam penelitian ini adalah Rancangan Acak Lengkap (RAL) yang disusun secara sederhana. Faktor perlakuan yang dicobakan terdiri dari 1 faktor dan diulang sebanyak 4 kali ulangan sehingga jumlah sampel sebanyak 20. Data dianalisa menggunakan Analisa Ragam, dan akan dilanjutkan uji BNT (Beda Nyata Terkecil) dengan taraf a 5\%.

\section{HASIL DAN PEMBAHASAN \\ Sifat Kimia Cookies}

Hasil analisa kimia cookies meliputi Kadar Air, Kadar Abu, Kadar Protein, Kadar Lemak, Kadar Karbohidrat, Kadar Serat dan Kadar Antioksidan yang disajikan pada Tabel 1. 
Tabel 1. Hasil Analisa Kimia Cookies

\begin{tabular}{|c|c|c|c|c|c|c|c|}
\hline Perlakuan & $\begin{array}{c}\text { K.Air } \\
(\%)\end{array}$ & $\begin{array}{c}\text { K.Abu } \\
(\%)\end{array}$ & $\begin{array}{c}\text { Protein } \\
(\%)\end{array}$ & $\begin{array}{c}\text { Lemak } \\
(\%)\end{array}$ & $\begin{array}{l}\text { Karbo- } \\
\text { hidrat } \\
(\%)\end{array}$ & $\begin{array}{c}\text { Serat } \\
(\%)\end{array}$ & $\begin{array}{l}\text { Antiok- }^{-} \\
\text {sidan } \\
(\%) \\
\end{array}$ \\
\hline $\begin{array}{l}\text { K1 : Tepung Terigu } 40 \mathrm{~g} \\
+ \text { Tepung Talas } 50 \mathrm{~g} \\
+ \text { Tepung Daun kelor } 10 \\
\mathrm{~g}\end{array}$ & $1,92^{\mathrm{d}}$ & $2,11^{\mathrm{e}}$ & 7,52 e & $23,34^{b}$ & $68,82^{\text {a }}$ & $0,10^{\mathrm{a}}$ & $64,77^{\mathrm{e}}$ \\
\hline $\begin{array}{l}\text { K2 : Tepung Terigu } 40 \mathrm{~g} \\
\text { +Tepung Talas } 52 \mathrm{~g} \\
\text { +Tepung Daun kelor } 8 \mathrm{~g}\end{array}$ & $1,86^{c}$ & $2,05^{\mathrm{d}}$ & $6,08^{d}$ & $23,26^{\mathrm{b}}$ & $69,34^{\mathrm{b}}$ & $0,11^{\mathrm{a}}$ & $57,45^{d}$ \\
\hline $\begin{array}{l}\text { K3 : Tepung Terigu } 40 \mathrm{~g} \\
\text { +Tepung Talas } 54 \mathrm{~g} \\
+ \text { +Tepung Daun kelor } 6 \mathrm{~g}\end{array}$ & $1,71^{b}$ & $1,92^{\mathrm{c}}$ & $6,30^{\mathrm{c}}$ & $22,69 \mathrm{~b}$ & $69,79^{\mathrm{c}}$ & $0,13^{\mathrm{b}}$ & $52,66^{\mathrm{c}}$ \\
\hline $\begin{array}{l}\text { K4 : Tepung Terigu } 40 \mathrm{~g} \\
+ \text { Tepung Talas } 56 \mathrm{~g} \\
+ \text { +Tepung Daun kelor } 4 \mathrm{~g}\end{array}$ & $1,63^{\mathrm{a}}$ & $1,87^{\mathrm{b}}$ & $5,73^{\mathrm{b}}$ & $22,38^{\mathrm{b}}$ & $70,51^{d}$ & $0,15^{\mathrm{c}}$ & $45,13^{b}$ \\
\hline $\begin{array}{l}\text { K5 : Tepung Terigu } 40 \mathrm{~g} \\
+ \text { Tepung Talas } 58 \mathrm{~g} \\
+ \text { +Tepung Daun kelor } 2 \mathrm{~g}\end{array}$ & $1,60^{\mathrm{a}}$ & $1,60^{\mathrm{a}}$ & 5,29 a & $21,56^{\text {a }}$ & $71,59 \mathrm{e}$ & $0,18^{d}$ & $38,27^{a}$ \\
\hline
\end{tabular}

Keterangan : Nilai rata-rata yang diikuti oleh huruf yang sama tidak berbeda nyata menurut uji BNT a 5\%

Berdasarkan data hasil analisa sidik ragam Cookies dengan penambahan subtitusi tepung talas dan tepung kelor berpengaruh sangat nyata terhadap kadar air. Semakin tinggi konsentrasi tepung kelor yang ditambahkan pada cookies dengan perlakuan subtitusi tepung kelor menghasilkan nilai kadar air yang semakin meningkat. Hal ini sesuai dengan pendapat Richana (2012) kadar air talas sebesar $146 \%$ dalam 100 g. Menurut penelitian Nuraini (2013) menunjukan bahwa dikarenakan rendahnya kadar air pada bahan makan akan membuat produk makin mudah dipatahkan.

Berdasarkan data hasil analisa sidik ragam Cookies dengan penambahan subtitusi tepung talas dan tepung kelor berpengaruh sangat nyata terhadap kadar abu. Hasil yang didapatkan dari data diatas kebanyakan melebihi dari standart SNI yang ditetapkan, hal ini dikarenakan tinggi rendahnya kadar abu suatu bahan disebabkan oleh kandungan mineral yang berbeda pada sumber bahan baku dan juga dapat dipengaruhi oleh proses demineralisasi saat pembuatan (Rizki, 2013).

Berdasarkan data hasil analisa sidik ragam Cookies dengan penambahan subtitusi tepung talas dan tepung kelor berpengaruh sangat nyata terhadap kadar protein. Berdasarkan tabel diatas semakin tinggi konsentrasi tepung kelor yang ditambahkan, maka kadar protein pada cookies yang dihasilkan semakin tinggi. Hal ini disebabkan tepung daun kelor memiliki protein yang lebih tinggi dibandingkan tepung talas yaitu sebesar 6,8\% (Fuglie, 2001). Sedangkan kadar protein talas menurut Richana (2012) sebesar 1,12\%. 
Berdasarkan data hasil analisa sidik ragam Cookies dengan penambahan subtitusi tepung talas dan tepung kelor berpengaruh sangat nyata terhadap kadar lemak. Hal ini disebabkan oleh semakin banyak penggunaan bahan tepung daun kelor dan tepung terigu, maka kadar lemak akan semakin meningkat (Usman, 2013). Besarnya kisaran kadar lemak cookies dari penelitian ini juga dipengaruhi oleh margarin dan shortening yang digunakan. Cookies sendiri berasal dari adonan lunak yang mengandung lemak yang cukup tinggi. Penurunan kadar lemak disebabkan disebabkan oleh perbedaan pada penggunaan bahan yang digunakan yaitu pada tepung daun kelor 2,3\% (Lowell, 1999), pada tepung talas $1,25 \%$ (Ridal, 2003) dan pada tepung terigu sebesar 1,5\% (Sunarsi dkk, 2011).

Berdasarkan data hasil analisa sidik ragam Cookies dengan penambahan subtitusi tepung talas dan tepung kelor berpengaruh sangat nyata terhadap kadar karbohidrat. Dapat disimpulkan bahwa semakin tinggi penambahan tepung talas maka kandungan nilai karbohidrat semakin tinggi. Hal ini sesuai pendapat (Richana, 2012) bahwa kadar karbohidrat pada 100g talas sebesar 24,5 gram. Sehingga sumbangan karbohidrat terbesar didapat dari tepung talas, sedangkan kadar karbohidrat dari kelor yaitu 12,5g dalam 100g bahan (Fuglie, 2001).

Berdasarkan data hasil analisa sidik ragam Cookies dengan penambahan subtitusi tepung talas dan tepung kelor berpengaruh sangat nyata terhadap kadar kadar serat. Semakin tinggi serat kasar yang diperoleh maka semakin tinggi pula kadar abu yang dihasilkan. Keberadaan serat kasar yang tinggi mampu meningkatkan kadar abu yang terdapat dalam bahan yang selanjutnya akan berpengaruh terhadap kualitas makanan (Siska,dkk 2009). Oleh karena itu, serat yang terdapat pada bahan makanan ataupun produk makanan dapat mengikat kandungan mineral yang terdapat pada produk cookies substitusi tepung talas dan tepung daun kelor.

Berdasarkan data hasil analisa sidik ragam Cookies dengan penambahan subtitusi tepung talas dan tepung kelor berpengaruh sangat nyata terhadap kadar antioksidan. Senyawa yang memiliki kontribusi terhadap aktivitas antioksidan dalam daun kelor adalah vitamin C, betakaroten, dan fenol (Engle, 2002). Daun kelor merupakan daun yang mengandung berbagai zat kimia yang bermanfaat. Fitokimia dalam kelor adalah tannin, steroid dan triterpenoid, flavonoid, saponin, antarquinon, dan alkaloid, dimana semuanya merupakan antioksidan (Kasolo dkk., 2010). Antioksidan di dalam daun kelor mempunyai aktivitas menetralkan radikal bebas sehingga mencegah kerusakan oksidatif pada sebagian besar biomolekul dan menghasilkan proteksi terhadap kerusakan oksidatif secara signifikan (Sreelatha dan Padma, 2012). 


\section{Sifat Fisik Cookies}

Hasil analisa sifat fisik cookies meliputi Tekstur (Daya Patah) dan Intensitas warna kehijauan(a-).

Tabel 2. Hasil Analisa Tekstur / Daya Patah Cookies

\begin{tabular}{cc}
\hline Perlakuan & $\begin{array}{c}\text { Tekstur } \\
\left(\mathrm{N} / \mathrm{m}^{2}\right)\end{array}$ \\
\hline K1 :Tepung Terigu 40 g +Tepung Talas 50 g +Tepung Daun kelor 10 g & $24,53^{\mathrm{a}}$ \\
K2 : Tepung Terigu 40 g +Tepung Talas 52 g +Tepung Daun kelor 8 g & $26,53^{\mathrm{b}}$ \\
K3 : Tepung Terigu 40 g +Tepung Talas 54 g +Tepung Daun kelor 6 g & $26,78^{\mathrm{c}}$ \\
K4 : Tepung Terigu 40 g +Tepung Talas 56 g +Tepung Daun kelor 4 g & $27,20^{\mathrm{c}}$ \\
K5 : Tepung Terigu 40 g +Tepung Talas 58 g +Tepung Daun kelor 2 g & $36,43^{\mathrm{d}}$ \\
\hline
\end{tabular}

Keterangan : Nilai rata-rata yang diikuti oleh huruf yang sama tidak berbeda nyata menurut uji BNT a $5 \%$

Penambahan margarin dalam adonan dapat menjadikan produk lebih lembut. Selain itu, lemak juga berfungsi sebagai pemberi flavor. Penggunaan margarin juga akan menghasilkan produk yang rapuh dan kering. Penambahan telur berpengaruh terhadap tekstur produk patiseri. Sebagai hasil dari fungsi. Penggunaan telur merupakan emulsifikasi, pelembut tekstur, dan daya pengikat pengikat bahan-bahan lain, sehingga struktur cookies lebih stabil. Putih telur bersifat sebagai pengikat atau pengeras (Faridah, 2008).

Tingkat kekerasan dipengaruhi oleh jumlah lemak yang rendah. Hal ini dapat membuat tekstur makanan menjadi keras atau tidak lunak karena lemak cenderung menyebabkan gel tepung menjadi lunak. Selain itu Penambahan gula mempengaruhi tekstur dalam snack bar menjadi lebih keras, karena adanya pemanasan, struktur gula meleleh dan setelah dingin struktur gulanya mengkristal kembali (Soeseno, 2008). Tekstur bersifat kompleks dan terkait dengan struktur bahan, yang terdiri dari tiga elemen yaitu mekanik (kekerasan dan kekenyalan), geometrik (berpasirdan beremah) dan mouthfeel (berminyak dan berair). Pada umumnya, bahan yang dinilai diletakkan diantara permukaan ibu jari, telunjuk atau jari tengah (Setyaningsih, dkk. 2010). 


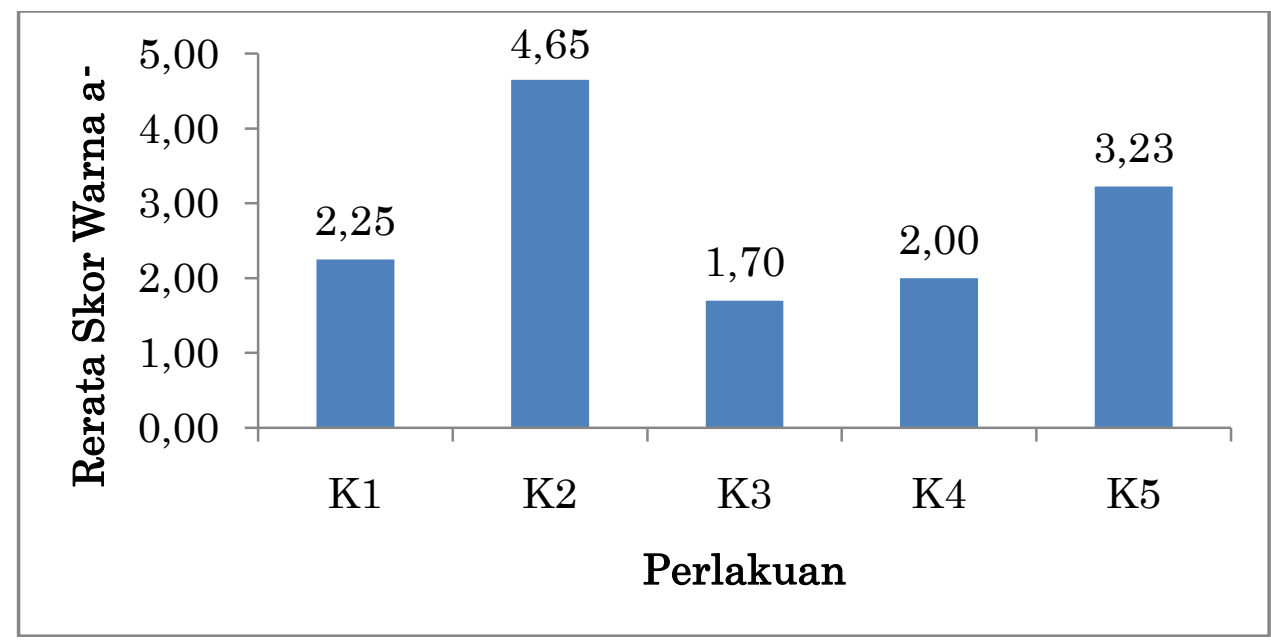

Gambar 1. Histogram Intensitas Warna Kehijauan Cookies

\section{Keterangan}

K1 : Tepung Terigu $40 \mathrm{~g}+$ Tepung Talas $50 \mathrm{~g}+$ Tepung Daun kelor $10 \%$ K2 : Tepung Terigu $40 \mathrm{~g}+$ Tepung Talas $52 \mathrm{~g}+$ Tepung Daun kelor $8 \%$ K3 : Tepung Terigu $40 \mathrm{~g}+$ Tepung Talas $54 \mathrm{~g}+$ Tepung Daun kelor $6 \%$ K4 : Tepung Terigu $40 \mathrm{~g}+$ Tepung Talas $56 \mathrm{~g}+$ Tepung Daun kelor $4 \%$ K5 : Tepung Terigu $40 \mathrm{~g}+$ Tepung Talas $58 \mathrm{~g}+$ Tepung Daun kelor $2 \%$

Adapun warna dari cookies tepung daun kelor adalah hijau, karena tepung daun kelor berwarna hijau. Hal ini dikarenakan tepung daun kelor mengandung klorofil. Hal ini didukung oleh Nanik Fitriani (2016), Warna hijau pada daun kelor disebabkan adanya klorofil. Daun kelor muda yang berwarna hijau muda dan berubah menjadi hijau tua pada daun yang sudah tua. Daun kelor saat kering berubah warna menjadi lebih gelap karena warna hijau klorofil pada daun teroksidasi menjadi lebih gelap. Besarnya tingkat konsentrasi yang ditambahkan akan mempengaruhi warna yang dihasilkan pada cookies. Semakin banyak penggunaan tepung daun kelor maka semakin bertambah hijau cookies tersebut.

\section{Organoleptik}

Rasa, Kenampakan, Kesukaan

Nilai rerata uji organoleptik rasa, kenampakan dan kesukaan cookies substitusi tepung talas dan tepung daun kelor tertera pada Gambar 2, 3 dan 4.

Hal ini terjadi karena adanya rasa khas yang ditimbulkan oleh daun kelor. Rasa ini muncul karena di dalam daun kelor terdapat tanin yang memberikan dampak rasa sepat dan pahit (Rosyida, 2016). Rasa pahit pada tepung kelor disebabkan karena terkandung senyawa tanin di dalam daun kelor. Tanin dapat menyebabkan rasa sepat karena saat dikonsumsi akan terbentuk ikatan silang antara tanin dengan protein atau glikoprotein di rongga mulut sehingga 
menimbulkan perasaan kering dan berkerut (Yulianti, 2008).

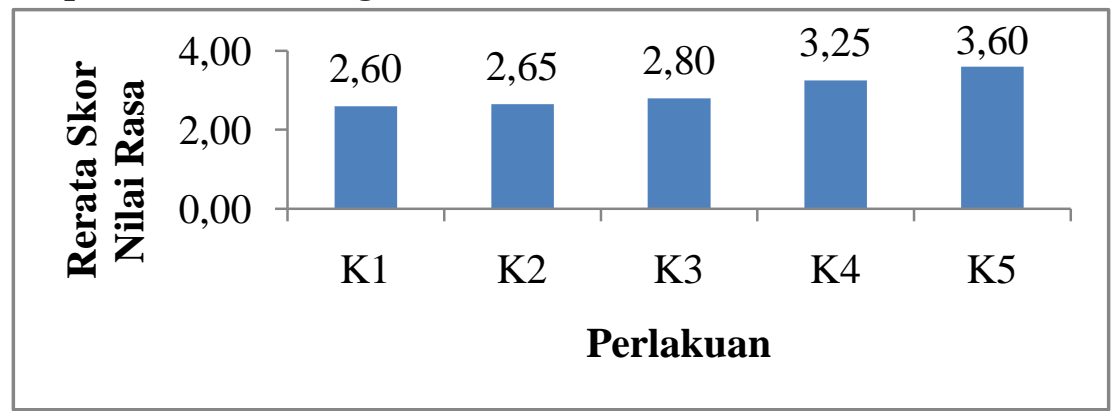

Gambar 2. Histogram Skor Uji Organoleptik Rasa

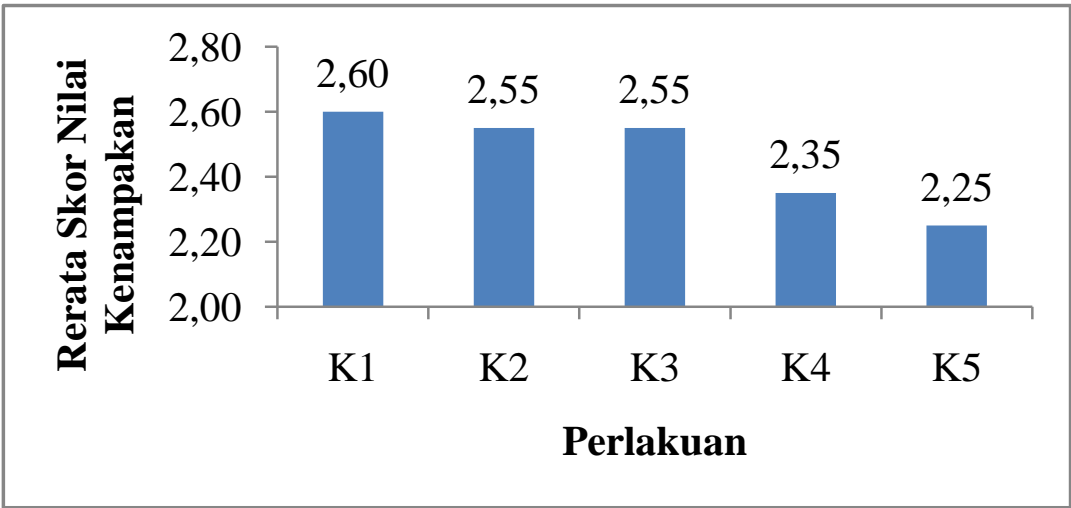

Gambar 3. Histogram Skor Nilai Uji Organoleptik Kenampakan

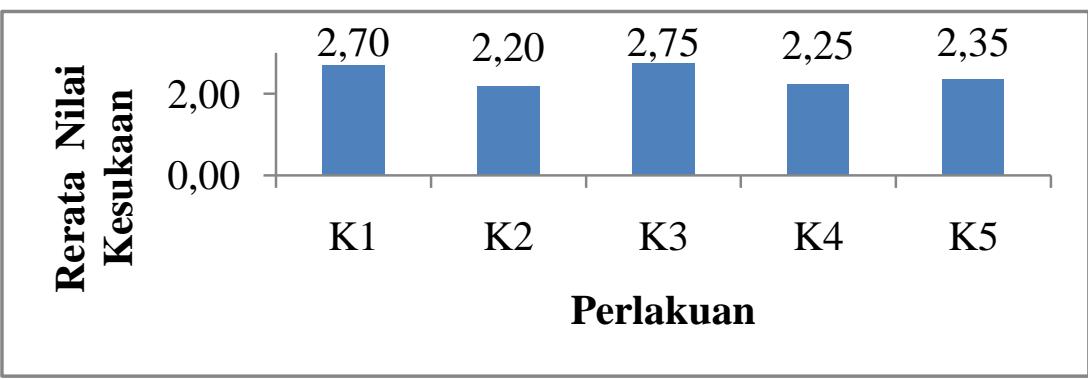

Gambar 4. Histogram Skor Nilai Uji Organoleptik Kesukaan

Keterangan :

T1K1 : Tepung Terigu $40 \mathrm{~g}+$ Tepung Talas $50 \mathrm{~g}+$ Tepung Daun kelor $10 \mathrm{~g}$ T2K2 : Tepung Terigu $40 \mathrm{~g}+$ Tepung Talas $52 \mathrm{~g}+$ Tepung Daun kelor $8 \mathrm{~g}$ T3K3 : Tepung Terigu $40 \mathrm{~g}+$ Tepung Talas $54 \mathrm{~g}+$ Tepung Daun kelor $6 \mathrm{~g}$ T4K4 : Tepung Terigu $40 \mathrm{~g}+$ Tepung Talas $56 \mathrm{~g}+$ Tepung Daun kelor $4 \mathrm{~g}$ T5K5 : Tepung Terigu $40 \mathrm{~g}+$ Tepung Talas $58 \mathrm{~g}+$ Tepung Daun kelor $2 \mathrm{~g}$

Dari hasil Uji organoleptik kenampakan menurut panelis perlakuan K1 warna yang lebih hijau, hal ini dikarenakan karena adanya penambahan tepung daun kelor $10 \mathrm{~g}$ yang dapat memberikan warna hijau. Hal ini disebabkan tepung daun kelor mengandung klorofil. Klorofil adalah zat wara hijau daun alami yang umumnya terdapat dalam daun sehingga sering disebut juga zat hijau 
daun. Daun kelor mengandung klorofil pada $6,890 \mathrm{mg} / \mathrm{kg}$ bahan kering. Sedangkan dalam 8 gram serbuk daun kelor mengandung $162 \mathrm{mg}$ klorofil (Krisnadi, 2012).

Menurut Meilgaard, et.al (1999) warna merupakan atribut penampilan pada produk pangan yang sering menentukan tingkat penerimaan konsumen terhadap produk tersebut secara keseluruhan.

Dari hasil Uji organoleptik kesukaan menurut panelis perlakuan K2 memiliki rasa yang pahit akibat adanya penambhan tepung kelor, selain itu warna yang lebih hijau kecoklatan,terjai karena pemanggangan yang tidak merata dan lebih tebal sehingga memerlukan waktu pemanggangan yang lebih lama. Warna merupakan kesan pertama yang diperoleh dari konsumen yang berasal dari suatu produk pangan.

\section{Uji Perbandingan Cookies Talas dan Kelor dengan Kontrol}

Parameter kesukaan cookies ditentukan dari rasa dan kenampakan cookies. Jika rasanya enak maka panelis akan suka demikian soal kenampakan, jika warna dan bentuk dari cookies tersebut menarik panelis maka panelis akan suka. Indera pencicip dan penglihatan merupakan dua dari lima indera dalam tubuh yang sangat umum untuk penilaian suatu makanan (Soekarto, 1985).

Kadar air pada cookies substitusi tepung talas dan tepung daun kelor perlakuan terbaik menunjukan perbedaan yang nyata terhadap kadar air cookies kontrol. Pada cookies perlakuan terbaik terdapat penambahan berupa tepung talas 58\% + tepung daun kelor 2\%. Menurut Richana, (2012) Kandungan kadar air pada talas mentah per100g berkisar 73\% dan menurut Fuglie (2001) kadar air pada daun kelor per100g yaitu sebesar $75 \%$.

Tabel 3. Perbandingan Sifat Kimia Cookies Talas Dan Kelor

\begin{tabular}{lrrrr}
\hline \multicolumn{1}{c}{ Parameter } & Cookies & \multicolumn{1}{c}{ Cookies } & \multirow{2}{*}{ Uji T } & NOTASI \\
\hline Kadar Air \% & 1,96 & 2,51 & 17,89 & $*$ \\
Kadar Abu \% & 1,61 & 1,40 & 2,80 & $*$ \\
Kadar Protein \% & 5,73 & 6,27 & 6,95 & $*$ \\
Kadar Lemak \% & 21,56 & 27,60 & 42,00 & $*$ \\
Karbohidrat (by difference) & 71,59 & 52,43 & 41,57 & $*$ \\
Serat Kasar \% & 0,07 & 0,64 & 12,74 & $*$ \\
Antioksidan \% & 38,27 & 40,48 & 5,82 & $*$ \\
Warna A+ & 3,23 & 4,28 & 0,76 & ns \\
Tekstur N/m ${ }^{2}$ & 36,93 & 38,36 & 0,33 & ns \\
\hline
\end{tabular}

Keterangan $:(*)=$ nyata,$(\mathrm{ns})=$ tidak nyata

Kadar Abu pada cookies substitusi tepung talas dan tepung daun kelor 
perlakuan terbaik menunjukan perbedaan yang nyata terhadap kadar abu cookies kontrol. Pada cookies perlakuan terbaik terdapat penambahan berupa tepung talas $58 \%+$ tepung daun kelor 2\%. Hal ini dikarenakan talas mentah mengandung kalsium sebesar $32 \mathrm{mg}$ dan fosfor sebesar $70 \mathrm{mg}$ per $100 \mathrm{~g}$. Richana, (2012) dan pada tepung daun kelor mengandung kalsium sebesar 440mg dan fosfor $259 \mathrm{mg}$ per100g tepung talas. Fuglie, (2001).

Kadar protein pada cookies substitusi tepung talas dan tepung daun kelor perlakuan terbaik menunjukan perbedaan yang nyata terhadap kadar protein cookies kontrol. Pada cookies perlakuan terbaik terdapat penambahan berupa tepung talas 58\% + tepung daun kelor 2\%. Menurut Richana (2012) kandungan protein pada talas mentah $100 \mathrm{~g}$ yaitu sebesar $1,12 \mathrm{~g}$ dan Menurut Fuglie(2001) kadungan protein pada tepung daun kelor per100g yaitu sebesar $6,8 \mathrm{~g}$.

Kadar lemak pada cookies substitusi tepung talas dan tepung daun kelor perlakuan terbaik menunjukan perbedaan yang nyata terhadap kadar lemak cookies kontrol. Pada cookies perlakuan terbaik terdapat penambahan berupa tepung talas $58 \%+$ tepung daun kelor $2 \%$. Hal ini dikarenakan pada talas mentah mengandung 0,10g lemak.Richana (2012) dan pada tepung daun kelor mengandung 1,7g lemak dalam 100g tepung.Fuglie(2001).

Kadar karbohidrat pada cookies substitusi tepung talas dan tepung daun kelor perlakuan terbaik menunjukan perbedaan yang nyata terhadap kadar karbohidrat cookies kontrol. Pada cookies perlakuan terbaik terdapat penambahan berupa tepung talas 58\% + tepung daun kelor 2\%. Menurut Richana.(2012) kandungan kadar karbohidrat pada talas mentah mengandung karbohidrat sebesar 24,50g dalam 100g talas sedangkan menurut Fuglie(2001) kadar karbohidart tepung daun kelor per100g yaitu sebesar 12,5g.

Kadar serat pada cookies substitusi tepung talas dan tepung daun kelor perlakuan terbaik menunjukan perbedaan yang nyata terhadap kadar serat cookies kontrol. Pada cookies perlakuan terbaik terdapat penambahan berupa tepung talas 58\% + tepung daun kelor 2\%. Menurut Richana, (2012) kadar serat pada $100 \mathrm{~g}$ talas mentah sebesar $1,46 \mathrm{~g}$ dan pada tepung daun kelor terdapat $0,9 \mathrm{~g}$ pada setiap 100gtepung daun kelor.Fuglie(2001)

Aktivitas antioksidan pada cookies substitusi tepung talas dan tepung daun kelor perlakuan terbaik menunjukan perbedaan yang nyata terhadap akktivitas antioksidan cookies kontrol. Pada cookies perlakuan terbaik terdapat penambahan berupa tepung talas 58\% + tepung daun kelor 2\%. Dapat disimpulkan bahwa semakin besar penambahan konsentrasi daunkelor maka semakin tinggi hasil uji aktivitas antioksidan pada cookies substitusi tepung talas dan tepung daun kelor karena pada daun kelor terdapat senyawa yang mengkontribusi aktivitas antioksidan pda daun kelor yaitu vitamin $\mathrm{C}$, 
betakaroten dan fenol (Engle, 2002).

\section{KESIMPULAN}

Berdasarkan hasil penelitian Proses Pembuatan Cookies Substitusi Tepung Talas (Colocasia esculenta (L) Schot) dan Tepung Daun Kelor (Moringa Oleifera Lamk) dapat diambil kesimpulan bahwa substitusi tepung talas dan tepung daun kelor berpengaruh sangat nyata terhadap kadar air, kadar abu, kadar protein, kadar lemak, kadar karbohidrat, kadar serat dan tekstur daya patah cookies. Penggunaan tepung talas dan tepung daun kelor berpengaruh sangat nyata terhadap aktivitas antioksidan.

\section{REFERENSI}

Fuglie, Lowell J., ed. 2001. The Miracle Tree: The multiple attributes of moringa. Dakar, Senegal: Church World Service

Jefriando. 2013. Dalam penelitian Asty Dewi Pangaribuan. (2013). Subtitusi Talas Belitung pada Pembuatan Biskuit Daun Kelor. Yogyakarta : Universitas Atma JayaYogyakarta.

Meilgaard M, GV Civille \& BT Carr. 1999. Sensory Evaluation Techniques. New York: CRC Press

Nurani, S.2013.Pemanfaatan Tepung Kimpul (Xanthosoma sagittifolium) sebagai Bahan Baku Cookies (Kajian Proporsi Tepung dan Penambahan Margarin). Jurnal Pangan dan Agroindustri, 2 (2): 50- 58.

Pratiwi, ST. 2008. Mikrobiologi Farmasi. Yogyakarta: Penerbit Erlangga.Halaman 176.

Rosyidah, A. Z. 2016. Studi tentang tingkat kesukaan responden terhadap penganekaragaman lauk pauk dari daun kelor (Moringa oleifera). Ejournal Boga, 5(1), 17-22

Rizki, A. 2011. Kajian Karakteristik Fisikokimia dan Organoleptik Snack bar dengan Bahan Dasar Tepung Tempe dan Buah Nangka Kering sebagai Alternatif Pangan CFGF (Casein Free Gluten Free). Skripsi Fakultas Pertanian Universitas Sebelas Maret. Surakarta.

Richana, N. 2012. Araceae \& D scorea : Manfaat Umbi - umbian Indonesia. Nuansa. Bandung. 95 hal

Ridal, S. 2003. Karakteristik sifat Fisiko-Kimia tepung dan pati talas (Colocasia esculenta) dan kimpul (Xanthosoma sp.) dan uji penerimaan $\alpha^{-}$ amilase terhadap patinya. Skripsi. Fakultas Teknologi Pertanian. IPB. Bogor. 60 hal.

Usman S, Nazir S, Ali S, Nasreen Z, Najim A. 2010. Determination of Biochemical Composition of Avena sativa (Oat) and to Estimate the Effect of High Fibre diet on Hypercholesteromic rats. 
Bangladesh Res Publ J 4: 312-319

Zakaria. 2012. Penambahan Tepung Daun Kelor Pada Menu Makanan Sehari hari Dalam Upaya Penanggulangan Gizi Kurang Pada Anak Balita. Makassar: Poltekkes Kesehatan Kemenkes Makassar. 